Osoba i doświadczenie mistyczne (2)

„Filozofia Chrześcijańska” 14 (2017), s. 87-105

doi: $10.14746 /$ fc.2017.14.5

\author{
MATEUSZ STRÓŻYŃSKI \\ Uniwersytet im. Adama Mickiewicza w Poznaniu \\ Wydział Filologii Polskiej i Klasycznej
}

\title{
Kontemplacja Boga u św. Augustyna w perspektywie ewolucji jego filozofii
}

Próba uchwycenia istoty kontemplacji Boga u Augustyna wyjść musi od wpływu pism Plotyna na życie i myśl biskupa Hippony ${ }^{1}$. Twórca neoplatonizmu był bowiem nie tylko jego głównym źródłem inspiracji, pomijając Pismo Święte, ale sam Augustyn wiąże swoje nawrócenie na chrześcijański ascetyzm, a przynajmniej decydującą fazę tejże konwersji, z lekturą libri platonicorum, które zasadniczo możemy utożsamić z dziełami Plotyna w łacińskim przekła$\mathrm{dzie}^{2}$. Nie będę tu streszczał głównych idei mistycyzmu autora Ennead, chcę

${ }^{1} \mathrm{Na}$ temat wpływu Plotyna na Augustyna istnieje wciąż rosnąca liczba publikacji. Zob. np. P. Alfaric, L'evolution intellectuelle de Saint Augustin, Paris 1918; C. Boyer, Christianisme et Neo-platonisme dans la formation de saint Augustin, Paris 1920; P. Courcelle, Recherches sur les Confessions de saint Augustin, Paris 1968, s. 51-56, 93-153, 211-221; R.J. O'Connell, Augustine's Early Theory of Man, A.D. 386 - 391, Cambridge 1968 and St. Augustine's Confessions. The Odyssey of Soul, New York 2003; E. Kevane, Christian Philosophy: the Intellectual Side of Augustine's Conversion, "Augustinian Studies" 17 (1986), s. 49-83; R. Crouse, Paucis mutatis verbis: St. Augustine's Platonism, w: Augustine and His Critics: Essays in Honour of Gerald Bonner, red. R. Dodaro, G. Lawless, London-New York 2000, s. 37-50; P. Cary, Augustine's Invention of the Inner Self. The Legacy of a Christian Platonist, Oxford 2000; B. Dobell, Augustine's Intellectual Conversion: the Journey from Platonism to Christianity, Cambridge 2009; J.P. Kenney, Contemplation and Classical Christianity: a Study in Augustine, Oxford 2013.

${ }^{2}$ Conf. 7.9.13 - 7.20.26. Uczeni formulują różne hipotezy dotyczące tego, czym w istocie były owe libri. Niektórzy sądzą, że były to dzieła Porfiriusza (W. Theiler, Porphyrios und Augustine, Halle 1933; E. TeSelle, Porphyry and Augustine, „Augustinian Studies” 5 (1974), s. 113-147; B. Dobell, Augustine's Intellectual Conversion ..., dz. cyt., s. 228-236). O'Connell i jego zwolennicy koncentrują się na Plotynie, choć sam O'Connell pod koniec życia podkreślał, że nie twierdzi, iż Augustyn nie czytał w Mediolanie Porfiriusza, a tylko, że nie znalazł żadnych dowodów, jakoby tak było, podczas gdy kontakt z tekstami Plotyna jest pewny (R. O'Connell, Where the Difference Still Lies, „Augustinian Studies” 21 (1990), s. 139-152, na s. 148). Wydaje się zatem, że lektura Plotyna 
przypomnieć tylko jej istotę, którą jest doświadczenie tożsamości centrum duszy i Jednego jako Centrum wszechrzeczy (przy obiektywnej nietożsamości tych podmiotów), co oznacza, że osiągnięte wysiłkiem samopoznanie najgłębszego punktu duszy z konieczności oznacza wejście w stan jedności ze Źródłem wszelkiego istnienia, w której nie ma żadnej możliwości rozróżnienia między „sobą” a „Jednym” czy między duszą a jej Źródłem³.

Warto jeszcze wspomnieć, że przez całe życie Augustyn był w swoim metafizycznym i epistemologicznym myśleniu filozofem ne oplat ońskim i przedstawiał neoplatonizm jako niepełną i obciążoną skazami wersję chrześcijaństwa, a raczej - chrześcijaństwo rozumiał jako vera philosophia, która dopełnia braki i ułomności neoplatonizmu ${ }^{4}$. Widać to w takich typowych miejscach, jak rozdział z ks. VII Wyznań, gdzie Augustyn powtarza swoje ibi legi/ /ibi non legi, porównując pisma Plotyna do Prologu Ewangelii Jana. Zdaniem biskupa Hippony, wszystko, co Ewangelia mówi o naturze Boga, można znaleźć również u Plotyna, nawet doktrynę Trójcy, nie można tam znaleźć natomiast wcielenia i zbawienia przez śmierć i zmartwychwstanie Logosu ${ }^{5}$. We wczesnym dziele De vera religione Augustyn powie, że neoplatonicy ,[...] stać się mogą chrześcijanami zmieniwszy zaledwie kilka słów i sformułowań"

jest poza wątpliwościami, natomiast lektura Porfiriusza rodzi wiele znaków zapytania. Pewne Porfiriańskie idee, które znajdują się we wczesnych tekstach Augustyna, można bowiem wywodzić nie tyle z tego, iż przyszły biskup Hippony czytał jego dzieła, ile raczej z faktu, że przebywając w neoplatońskim środowisku skupionym wokół biskupa Mediolanu, Ambrożego, Augustyn musiał się z tymi ideami zetknąć pośrednio - takie jest zdanie prof. Gillian Clark (rozmowa prywatna, 2015).

3 Zob. M. Stróżyński, Mistyka jaźni w filozofii Plotyna, „Filozofia Chrześcijańska” 13 (2016), s. $97-120$.

${ }^{4}$ Por. H.I. Marrou, Saint Augustin et la fin de la culture antique, Paris 1958, s. 638-643; A. Mandouze, Saint Augustin, l'aventure de la raison et de la grâce, Paris 1968, s. 246-288; F. Cayré, Initiation à la philosophie de saint Augustin, Paris 1947, s. 1-60; C. Stead, Philosophy in Christian Antiquity, Cambridge 1994, s. 79-93; J.M. Rist, Augustine: Ancient Thought Baptized, Cambridge 1994, s. 5-10; R. Teske, To Know God and the Soul: Essays on the Thought of Saint Augustine, Washington 2008, s. 4-13; F. van Fleteren, Augustine and Philosophy, „Augustinian Studies”, 41, 1, 2010, s. 255-274; G. Madec, Pour l'amour de l'intelligence (Augustin, Lettre 120, à Consentius). Foi - Raison - Intelligence, w: Augustinus Afer. Actes du colloque international Alger-Annaba, 1-7 avril 2001. Saint Augustin: africanité et universalité, (Paradosis, 45, 1-2), red. P.Y. Fux, J.M. Roessli, O. Wermelinger, Fribourg 2003, s. 237-241. Wniosek o trwałości Augustyńskiego zainteresowania neoplatonizmem płynie też z analizy korpusu jego listów (zob. M. Stróżyński, Neoplatonism in Augustine's Letters, w: Scrinium Augustini. The World of Augustine's Letters, red. P. Nehring, M. Stróżyński, R. Toczko, Turnhout 2017 [w druku]).

5 Conf. 7.9.13-15.

${ }^{6}[. .$.$] pancis mutatis verbis atque sententiis Christianis fierent (ver. rel. 5.7, Augustinus, De$ doctrina Christiana, De vera religione, ed. K.D. Daur, J. Martin, Turnhout 1962, s. 192). 


\section{Kontemplacja we wczesnym okresie twórczości Augustyna}

Wydaje się, że między rokiem 386 (gdy Augustyn zetknął się z mediolańskim kręgiem chrześcijańskich neoplatoników, którego przywódcą był Ambroży) a mniej więcej rokiem 395 - rokiem nie tylko wyświęcenia na biskupa Hippony, ale też początku pracy nad dziełkiem Ad Simplicianum (gdzie pojawia się po raz pierwszy sformułowanie peccatum originale) oraz nad Wyznaniami - Augustyn podąża wiernie za mistyką Plotyna poza dwiema zasadniczymi kwestiami. Dla ilustracji posłużę się odwołaniem do jednego z wczesnych tekstów, De quantitate animae, gdzie Augustyn przedstawia koncepcję siedmiu poziomów świadomości, po których dusza wznosi się do kontemplacji Boga. Jest ona oparta w dużym stopniu na Plotyńskiej koncepcji anabasis, wstępowania po kolejnych piętrach bytu. Zasadniczą metodą, podobnie jak u autora Ennead, jest oczyszczanie umysłu i serca od zgubnych wpływów zmysłowo-materialnych: dusza, pisze Augustyn, musi „oddzielić się od brudów” - jest to „praca oczyszczania”, „dzieło oczyszczenia”7.

Na poziomie szóstym i siódmym dusza kontempluje Boga - oczyszczone już oko umysłu wpatruje się w samą Prawdę - ale pojawia się tutaj zasadnicza w stosunku do Plotyna różnica. Bóg, Prawda czy Światło, o których mówi Augustyn, są kontemplowane ponad umysłem czy duszą człowieka i podmiot ludzki w żaden sposób nie jednoczy się ani nie utożsamia z Bogiem, a jedynie ogląda Go, podczas gdy u Plotyna Jedno, będące ponad duszą, staje się w kulminacyjnym momencie subiektywnie tożsame z ludzką jaźnią. Gdy Augustyn pisze, że poziom siódmy wstępowania jest „widzeniem i kontemplacją prawdy”, dodając, że „nie jest to już poziom, ale jakby siedziba"8, mamy tu swoisty obraz świetlistej przestrzeni, w której dusza ma stałą siedzibę i spoczynek, ale nie jest to jednak Plotyńskie zjednoczenie. Ściśle z tym związane jest odrzucenie przez Augustyna koncepcji twórcy neoplatonizmu, w myśl której Jedno jest ponad bytem ${ }^{9}$, a tym samym - ponad poznaniem, podczas gdy Bóg Augustyna bardziej przypomina Plotyński Intelekt, czyli Byt i Prawdę ${ }^{10}$. Z pewnością można Go poznać, inaczej niż u Grzegorza z Nyssy i Pseudo-Dionizego Areopagity, gdzie Bóg jest niepoznawalny, a kontakt z Nim następuje przez niewiedzę - w tym względzie więc koncepcja tych autorów chrześcijańskich podobna jest do mistycyzmu

${ }^{7}$ sese abstrahere a sordibus... purgationis negotium... opus mundationis - Quant. 73, Augustinus, De quantitate animae, ed. W. Hörmann, Vienna 1986, s. 221. Wszystkie poniższe tłumaczenia są mojego autorstwa.

${ }^{8}$ Mansio (Quant. 76, s. 223).

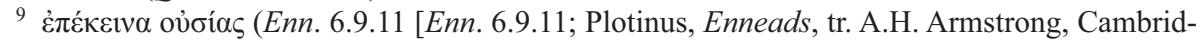
ge-London 2000-2003, vol. 7, s. 344]). Myśl ta wywodzi się od Platona (Resp. 509b).

10 Por. P. Cary, Augustine's Invention..., dz. cyt., s. 55-58. 
Plotyna ${ }^{11}$. Niepoznawalność Boga u Augustyna ma inny charakter, jest to raczej niezdolność skończonego umysłu do „ogarnięcia” tego, co nieskończone, niż istotowa niepoznawalność Boga.

Nic nie wskazuje na to, iż Augustyn nie rozumiał, że istota najwyższego doświadczenia mistycznego w Enneadach Plotyna była radykalnie inna. Augustyn nigdy albo prawie nigdy nie używa języka czy obrazowania związanego z jednością czy nawet zjednoczeniem duszy i Boga, mimo że język taki należy do uniwersalnego słownika mistyki tamtych czasów. W nauce dominuje pogląd, że Augustyn, w przeciwieństwie do ojców greckich, nie rozwinął nauki o theosis, przebóstwieniu, uczestnictwie w Bożej naturze. Polemizuje z tą tezą ostatnio David Vincent Meconi, w swojej książce o deifikacji u Augustyna ${ }^{12}$. Tutaj chcę jedynie zaznaczyć, że język teotyczny nie pojawia się w doktrynie kontemplacji Augustyna, choć wydaje się, że jest obecny w innych obszarach jego refleksji. Biskup Hippony unikał tego typu języka, pisząc o doświadczeniu mistycznym, ale, zarazem, nigdy tego nie uzasadniał, nigdy nie podawał argumentów za taką strategią, nigdy wprost nie wyartykułował tego zaskakującego dystansu wobec Plotyna, którego myśl w tak wielu innych obszarach przyjmował wiernie lub twórczo przekształcał.

Jak zasugerował już jakiś czas temu Bernard McGinn, powodem tego mogło być to, że Augustyn, po pierwsze, doskonale rozumiał, iż mistyka Plotyna osiąga kulminację w doświadczeniu braku różnicy między duszą a Bogiem, a po drugie, uważał taki sposób rozumienia doświadczenia Boga za niepożądany z chrześcijańskiej perspektywy ${ }^{13}$. Robert O’Connell w interesujący sposób interpretuje wywód Augustyna przeciwko bałwochwalstwu w księdze VII Wyznań jako ukrytą aluzję skierowaną właśnie przeciw mistyce Plotyna. Dodajmy - ukrytą bardzo skrzętnie, gdyż wielu uczonych zupełnie inaczej rozumie wspomniany passus ${ }^{14}$.

Druga różnica polega na tym, że u Augustyna, od samego początku, Bóg jest osobą, która aktywnie człowieka poszukuje, która pomaga mu we wstę-

${ }^{11}$ Klasyczna koncepcja niepoznawalności Boga: Grzegorz z Nyssy, De hom. op. 11.1-4; tenże, De vita Moysis 2.162-166; Pseudo-Dionizy Areopagita, Theol. Myst. 1.1. Na temat niepoznawalności Boga u Augustyna zob. V. Lossky, Les elements de "Théologie négative» dans la pensée de saint Augustin, w: Augustinus Magister, t. 2, Paris 1954, s. 575-581; D. Carabine, The Unknown God: Negative Theology in the Platonic Tradition, Plato to Eriugena, Louvain 1995, p. 259-260; P. Cary, Augustine's Invention..., dz. cyt., s. 53-60; R. Sorabji, Time, Mysticism, and Creation, w: Augustine's Confessions. Critical Essays, red. W.E. Mann, Oxford 2006, s. 209-236; P. van Geest, The Incomprehensibility of God: Augustine as a Negative Theologian, Leuven-Paris 2011.

12 D.V. Meconi, The One Christ: St. Augustine's Theology of Deification, Washington 2013.

13 B. McGinn, The Presence of God, t. 1: The Foundations of Mysticism, New York 1991, s. 242. Por. też P. Cary, Augustine's Invention ..., dz. cyt., s. 38-40.

14 R.J. O'Connell, St. Augustine's Early Theory..., dz. cyt., s. 100. Inaczej interpretuje to miejsce np. E. TeSelle, Porphyry and Augustine, „Augustinian Studies” 5 (1974), s. 113-147, na s. 122-123. 
powaniu duchowym, można z Nim prowadzić dialog, modlić się do Niego, prosić czy dziękować ${ }^{15}$. U Plotyna tego nie znajdujemy, nawet jeśli pojawia się w Enneadach kilka uwag na temat mistycznej modlitwy błagalnej, które można policzyć na palcach jednej ręki ${ }^{16}$. Ten aspekt dialogiczny, osobowy jest zaznaczony u Augustyna od początku (np. w pierwszych rozdziałach Soliloquia), ale nie dominuje we wczesnych tekstach.

Pomimo tych dwóch bardzo ważnych różnic Augustyn pozostaje w zgodzie ze swym neoplatońskim mistrzem, gdy mówi o tym, że celem drogi mistycznej jest stabilne, pewne wpatrywanie się w niezmiennego Boga, a metodą osiągnięcia tego jest oczyszczenie umysłu z przywiązania do zmysłów i wstępowanie po piętrach bytu i poznania. Augustyn w pierwszych latach swojej twórczości rozwijał oryginalny projekt, zgodnie z którym najlepszą metodą oczyszczenia jest siedem sztuk wyzwolonych, które przygotowują intelekt do kontemplacji $\mathrm{Boga}^{17}$. Na wczesnym etapie, gdy dusza nie jest jeszcze należycie oczyszczona, boskie Światło odrzuca jednak od siebie patrzącego, toteż często człowiek woli się wyrzec wszelkiego leczenia duszy i schronić się w ciemnościach ${ }^{18}$.

Wielu uczonych uważa ten wątek za bardziej biblijny niż neoplatoński, ale trzeba wspomnieć, że Plotyn pisze przecież o podobnym zjawisku duchowym:

A im bardziej dusza zbliża się do Bezforemnego, tym bardziej braknie jej sił, by Je objąć, gdyż ani nie ma Ono żadnych granic, ani nie przypomina kształtu wyciś-

15 Madec zwraca uwagę, że Plotyn nigdy nie mógłby zwrócić się do Boga „Ty”, tak jak czyni to nieustannie Augustyn (G. Madec, Une lecture de Confessions VII.9.13-21.27 (Notes critiques à propos d'une thèse de R.J. O'Connell), "Revue des Études Augustiniennes" 16 (1970), s. 79-137, na s. 88; por. też E.R. Dodds, Augustine's Confessions: a study of spirituals maladjustment, "Hibbert Journal" 26 (1926-1927), s. 459-473, na s. 171; J. Legowicz, Historia filozofii starożytnej Grecji i Rzymu, Warszawa 1973, s. 601; D. Dembińska-Siury, Byt i istnienie w filozofii Plotyna, Warszawa 1979, s. 46; T.F. Martin, Book Twelve: Exegesis and Confessio, w: A Reader's Companion to Augustine's Confessions, red. K. Paffenroth, R.P. Kennedy, Louisville-London 2003, s. 185-206, na s. 200; Kenney, Contemplation..., dz. cyt., passim.

${ }^{16}$ Najbardziej znany przykład takiej modlitwy znajduje się w Enn. 5.1.6.10-12. Na temat modlitwy u Plotyna oraz tradycji filozoficznego rozumienia modlitwy por. M. Atkinson, Plotinus: Ennead V.1. On the Three Principal Hypostases. A Commentary with Translation, Oxford 1983, s. 128-131; P.A. Meijer, Plotinus on the Good or the One (Enneads VI.9). An Analytical Commentary, Amsterdam 1992, s. 324.

${ }^{17} \mathrm{Na}$ temat tego ,projektu” szeroko piszą np. P. Cary, Augustine's Invention..., dz. cyt. oraz B. Dobell, Augustine's Intellectual Conversion ..., dz. cyt.

$18[\ldots]$ aliud est enim mundari oculum ipsum animae, ne frustra et temere aspiciat et praue uideat, aliud ipsam custodire atque firmare sanitatem, aliud iam serenum atque rectum aspectum in id, quod uidendum est, dirigere. quod qui prius uolunt facere quam mundati et sanati fuerint, ita illa luce reuerberantur ueritatis, ut non solum nihil boni, sed etiam mali plurimum in ea putent esse atque ab ea nomen ueritatis abiudicent et cum quadam libidine et uoluptate miserabili in suas tenebras, quas eorum morbus pati potest, medicinae maledicentes refugiant-(Quant. 75, s. 222). 
niętego przez jakąś kunsztowną formę, i ześlizguje się ona w obawie, że niczego nie osiągnie. Męczy się zatem tymi wysiłkami i z ulgą zstępuje w dół. (Enn. $6.9 .3)^{19}$

Zarówno u Plotyna, jak i u wczesnego Augustyna to „osuwanie się” duszy jest problemem przejściowym, wynikiem niedostatecznego przygotowania wewnętrznego. Gdy przezwycięży się jednak te trudności, można, jak pisze Augustyn, ,spokojne i proste spojrzenie ku Temu skierować” (serenum atque rectum aspectum in id... dirigere). Wydaje się więc, że podobnie jak Plotyn, Augustyn jest we wczesnym okresie swojej twórczości filozoficznej umiarkowanie optymistyczny co do możliwości stabilnego wpatrywania się w światło Prawdy, gdyż wierzy, że jest to możliwe do osiągnięcia w życiu doczesnym, choć przez niewielu jedynie filozofów, po gruntownym moralnym i intelektualnym oczyszczeniu duszy ${ }^{20}$.

\section{Kontemplacja w dojrzałej myśli Augustyna}

W połowie lat dziewięćdziesiątych IV wieku następuje u Augustyna znacząca zmiana, którą Brian Dobell nazywa „rewolucją paulińską” - bo związana była z lekturą listów św. Pawła - jest to niejako kolejne nawrócenie Augustyna $^{21}$. Jego owoce zbiegają się z początkiem posługi biskupiej w Hipponie. W myśleniu Augustyna zaczyna wtedy dominować doświadczenie grzechu jako pewnej choroby, która trawi ludzkość i z której człowiek sam nie jest w stanie się wyleczyć, a mistyka Augustyna zaczyna nabierać bardziej dramatycznego wymiaru ${ }^{22}$.

Możemy spojrzeć na swoisty zapis tej przemiany w podejściu Augustyna do grzechu w ks. VII Wyznań. Podczas lektury Ennead i wykonywania zalecanych przez Plotyna ćwiczeń duchowych Augustyn powiada

${ }^{19}$ Przekład: M. Stróżyński, Plotyn, O Dobru albo o Jednym (Enneada VI, 9), „Studia Antyczne i Mediewistyczne", 6, 41, 2008, s. 79-107.

${ }^{20}$ Równie ciekawe jest to, że jedyny kontekst, w którym taki język się pojawia, to kontekst eucharystyczny, czyli całkowicie obcy, niemożliwy do pogodzenia z mistyką Plotyna i pogańskim neoplatonizmem w całości. Jedyne zdanie Wyznań, które sugeruje, że dusza może w jakimś sensie przemienić się w Boga, stać się Bogiem czy zjednoczyć się z Nim, to zdanie „to Ty się we mnie przemienisz", odnoszące się do spożywania eucharystii, w księdze VII.

${ }^{21}$ B. Dobell, Augustine's Intellectual Conversion..., dz. cyt. Na temat tego nawrócenia w latach dziewięćdziesiątych pisze ostatnio również P. Rigby, The Theology of Augustine's Confessions, Cambridge 2015, s. 65-70.

${ }^{22}$ Na temat „dramatyzmu”, a także „liryzmu” Augustyńskiej koncepcji Boga ciekawie pisze P. Rigby (The Theology ..., dz. cyt., s. 214). 
ujrzałem jakimś okiem duszy mojej ponad tymże okiem mej duszy, ponad umysłem moim, Światło niezmienne; nie to światło pospolite i jawne dla każdego ciała ani też światło jakby tego rodzaju, tyle że wspanialsze, jak gdyby to światło jaśniało po wielekroć jaśniej i całą przestrzeń wypełniło swoim ogromem. Nie takie było to Światło, ale inne, zupełnie inne od wszystkich takich świateł. I nie było ono ponad moim umysłem w ten sposób, w jaki oliwa jest ponad wodą ani jak niebo ponad ziemią, lecz było ponad, ponieważ to ono mnie stworzyło, a ja byłem poniżej, ponieważ przez nie zostałem stworzony. Ten, kto zna prawdę, zna to Światło, a kto zna Prawdę, zna Wieczność. To Miłość ją zna. O wieczna Prawdo, prawdziwa Miłości i umiłowana Wieczności, Tyś jest Bogiem moim, ku Tobie wzdycham dniem i nocą! I gdy cię po raz pierwszy poznałem, przyciągnęłaś mnie, abym zobaczył, że to, co widziałem, istnieje, a ja, który to widziałem, jeszcze nie całkiem istnieję. I schłostałaś słabość mojego spojrzenia, potężnie mnie oświetlając, i zadrżałem z miłości i trwogi. I odkryłem, że daleko jestem od Ciebie w krainie niepodobieństwa. (Conf. 7.10.16)

Odnajdujemy tutaj nadal te elementy, o których wspomniałem na początku. Bóg jest neoplatońsko ujmowaną Prawdą, Światłem, niezmiennym Bytem, a doświadczenie mistyczne nie ma charakteru zjednoczenia przez niewiedzę, ale oglądania w świetle odrębnego przedmiotu. Augustyn pisze też:

ukoiłeś głowę nieświadomego i zamknąłeś oczy moje, by nie oglądały marności. Opuściłem na chwilę siebie i usnął mój obłęd; przebudziłem się w Tobie i - innym wzrokiem - ujrzałem, że jesteś nieskończony. (Conf. 7.14.20) $)^{24}$

${ }^{23}[. .$.$] et inde admonitus redire ad memet ipsum, intravi in intima mea duce te, et potui, quo-$ niam factus es adiutor meus. intravi et vidi qualicumque oculo animae meae supra eundem oculum animae meae, supra mentem meam, lucem incommutabilem, non hanc vulgarem et conspicuam omni carni, nec quasi ex eodem genere grandior erat, tamquam si ista multo multoque clarius claresceret totumque occuparet magnitudine. non hoc illa erat sed aliud, aliud valde ab istis omnibus. nec ita erat supra mentem meam, sicut oleum super aquam nec sicut caelum super terram, sed superior, quia ipsa fecit me, et ego inferior, quia factus ab ea. qui novit veritatem, novit eam, et qui novit eam, novit aeternitatem; caritas novit eam. o aeterna veritas et vera caritas et cara aeternitas, tu es deus meus, tibi suspiro die ac nocte! et cum te primum cognovi, tu adsumpsisti me ut viderem esse quod viderem, et nondum me esse qui viderem. et reverberasti infirmitatem aspectus mei, radians in me vehementer, et contremui amore et horrore. et inveni longe me esse a te in regione dissimilitudinis, tamquam audirem vocem tuam de excelso: 'cibus sum grandium: cresce et manducabis me. nec tu me in te mutabis sicut cibum carnis tuae, sed tu mutaberis in me.' et cognovi quoniam pro iniquitate erudisti hominem, et tabescere fecisti sicut araneam animam meam, et dixi, 'numquid nihil est veritas, quoniam neque per finita neque per infinita locorum spatia diffusa est?' et clamasti de longinquo, 'immo vero ego sum qui sum.' et audivi, sicut auditur in corde, et non erat prorsus unde dubitarem, faciliusque dubitarem vivere me quam non esse veritatem, quae per ea quae facta sunt intellecta conspicitur (Augustinus, Confessiones, ed. J.J. O'Donnell, wyd. elektroniczne: www.stoa. org/hippo).

${ }^{24}[. .$.$] fovisti caput nescientis et clausisti oculos meos, ne viderent vanitatem. cessavi de me$ paululum, et consopita est insania mea, et evigilavi in te et vidi te infinitum aliter. Być może vidi 
Podobnie jak wczesny obraz mansio, także i ten urywek mówi o byciu w Bogu, ale z zachowaniem odrębności podmiotu ludzkiego.

Pojawia się również motyw „schłostania” (reverberatio), odrzucenia od tego widzenia, wywołanego grzesznością duszy. Może się wydać, że nic się tu nie zmienia w stosunku do wczesnych pism. Jednak dokładniejsza lektura VII ks. Wyznań ujawnia, że w istocie Augustyn krytykuje swoje wcześniejsze podejście, ogłaszając klęskę swojego projektu oczyszczenia duszy przez sztuki wyzwolone i stabilnej kontemplacji Boga. Nie ma tu miejsca na szczegółowe przedstawienie sprawy, ale wiele przemawia za tym, że Augustyn w ks. VII nie tyle opisuje kilka miesięcy z roku 386, ile całe dziesięciolecie, począwszy od tego roku do przełomu paulińskiego ${ }^{25}$. Księga VII wskazuje również na przyczynę porażki - grzech pierworodny, obezwładniający władze duszy.

Już w zacytowanym tekście, a także w innych miejscach Wyznań, pojawia się nowy akcent na relacyjny, miłosny charakter doświadczenia mistycznego. Podobnie jak motyw niezdolności duszy do poznania Boga, wątek ten był w pewnym stopniu obecny również i we wcześniejszych pismach, ale tutaj zaczyna on wyraźnie dominować nad metafizycznym ujęciem Boga jako niezmiennego Bytu i Prawdy. Niezdolność, wynikająca z fundamentalnego niepodobieństwa do Boga, okazuje się o wiele trwalsza i w zasadzie niemożliwa do pokonania, a wymiar relacyjny mistyki staje się dramatycznym spotkaniem człowieka z wszechmocną Osobą, która aktywnie pomaga Augustynowi w wejściu w siebie i osiągnięciu kontemplacji (wątek u Plotyna nieobecny).

U Plotyna istnieje eros rozumiany jako pragnienie, pożądanie Boga, którego kulminacją jest zjednoczenie się z Nim bez różnicy. Bóg jest jednak platońskim ukochanym, który pozostaje biernym obiektem pożądania i zachwytu. W doświadczeniu Augustyna metafizyczne Światło, Prawda i Byt stają się coraz bardziej aktywną, kochającą Osobą, która przyciąga go (adsumpsisti) do siebie, chcąc go, mówiąc wprost, „zjeść” z miłości. Bóg mówi bowiem, że gdy Augustyn dojrzeje do spożywania eucharystii, to nie on będzie wchłaniał w siebie Boga, ale raczej „w Boga się przemieni”, bo Bóg go wchłonie w siebie. Ciekawe, że jedyna możliwość teotycznego zjednoczenia ma charakter eucharystyczny, bardzo zmysłowy i sakramentalny, zupełnie nieplotyński. W innych dziełach Augustyna ten wymiar teotyczny i zjednoczeniowy widoczny

te infinitum aliter stanowi aluzję do Enn. 1.6.8.25-28 i 6.9.11.23. Wątek marności zaczerpnięty jest z Psalmu 118,37, ale też, oczywiście, z Eklezjastesa. Chevallier i Rondet nie omawiają tego miejsca w swoim studium o motywie marności u Augustyna, choć z pieczołowitością odnotowują o wiele mniej oczywisty obraz pająka z Conf. 10.35.57. Pokazują też, jak Augustyn łączy biblijną tradycję z Platońską koncepcją świata nie-bytu i przemijania (L. Chevallier, H. Ronder, L'idée de Vanité dans l'oeuvre de saint Augustin, „Revue des Études Augustiniennes” 3 (1957), s. 221-234).

${ }^{25}$ Zob. np. R.J. O'Connell, St. Augustine's Confessions..., dz. cyt., s. 103. Por. też P. Cary, Augustine's Invention..., dz. cyt., s. 116 oraz B. Dobell, Augustine's Intellectual Conversion..., dz. cyt., s. 25-27. 
jest w teologii Kościoła, czyli też w obszarze zmysłowym, sakramentalnym i wspólnotowym ${ }^{26}$.

Zmiana, jaka następuje w mistycyzmie Augustyna, polega więc z jednej strony na podkreśleniu niepodobieństwa człowieka do Boga, bolesnego oddzielenia wywołanego grzechem, a z drugiej - na wyeksponowaniu relacyjności kontaktu mistycznego. W jakimś sensie drugi element umożliwia pokonanie pierwszej trudności, Boża inicjatywa ratuje człowieka z paraliżu grzechem. Nieco dalej w tej samej ks. VII Augustyn jednak pisze o wstępowaniu do Boga bez odwołania się do tych nowych elementów, akcentując swój wysiłek i pokazując neoplatońskie wstępowanie:

A tak oto stopień po stopniu wznosiłem się od ciał do odczuwającej za pośrednictwem ciała duszy, a stamtąd do tej wewnętrznej mocy duszy, której zmysły cielesne przynoszą wieści [...], a stamtąd wznosiłem się dalej do zdolności rozumowania [...]. I dotarła ta zdolność duszy do tego, co istnieje, w momencie drżącego widzenia. Wtedy zaiste ujrzałem umysłem niewidziane przymioty Twoje poprzez to, co zostało przez Ciebie stworzone. (Conf. 7.17.23) ${ }^{27}$

Doświadczenie pełnej mistycznej kontemplacji trwa jednak tylko pewien czas. Augustyn znowu powtarza bowiem: „nie mogłem wytrwać w patrzeniu i gdy moja słabość została odepchnięta przez Ciebie i powróciłem do codziennej świadomości, zabrałem ze sobą tylko kochającą pamięć, pożądającą czegoś, czego zapach czułem, ale nie mogłem tego jeszcze spożywać" (Conf. 7.17.23) ${ }^{28}$. „Odepchnięcie” (repercussio) oznacza tu to samo, co wcześniejsze „schłostanie" (reverberatio).

${ }^{26} \mathrm{~Np}$. In epistulam Ioannis tractatus 10.3, gdzie pada słynne zdanie, że Kościół to ,jeden Chrystus kochający samego siebie" (unus Christus amans seipsum, PL 35, s. 2055).

27 [...] quaerens enim unde approbarem pulchritudinem corporum, sive caelestium sive terrestrium, et quid mihi praesto esset integre de mutabilibus iudicanti et dicenti, 'hoc ita esset debet, illud non ita' - hoc ergo quaerens, unde iudicarem cum ita iudicarem, inveneram incommutabilem et veram veritatis aeternitatem supra mentem meam commutabilem. atque ita gradatim a corporibus ad sentientem per corpus animam atque inde ad eius interiorem vim, cui sensus corporis exteriora nuntiaret, et quousque possunt bestiae, atque inde rursus ad ratiocinantem potentiam ad quam refertur iudicandum quod sumitur a sensibus corporis. quae se quoque in me comperiens mutabilem erexit se ad intellegentiam suam et abduxit cogitationem a consuetudine, subtrahens se contradicentibus turbis phantasmatum, ut inveniret quo lumine aspergeretur, cum sine ulla dubitatione clamaret incommutabile praeferendum esse mutabili unde nosset ipsum incommutabile (quod nisi aliquo modo nosset, nullo modo illud mutabili certa praeponeret), et pervenit ad id quod est in ictu trepidantis aspectus. tunc vero invisibilia tua per ea quae facta sunt intellecta conspexi, sed aciem figere non evalui.

${ }^{28}[. .$.$] pervenit ad id quod est in ictu trepidantis aspectus. tunc vero invisibilia tua per ea$ quae facta sunt intellecta conspexi, sed aciem figere non evalui, et repercussa infirmitate redditus solitis non mecum ferebam nisi amantem memoriam et quasi olefacta desiderantem quae comedere nondum possem. 
W słynnej wizji z Ostii, zamieszczonej w ks. IX Wyznań, Augustyn znowu opisuje neoplatońskie wstępowanie, w języku pełnym parafraz Plotyna ${ }^{29}$, tym razem jednak ćwiczenie wykonywane jest wraz z jego matką, Moniką, i samo doświadczenie wydaje się również uwspólnione, czego u twórcy neoplatonizmu nie znajdujemy:

przemierzyliśmy stopień po stopniu wszystkie byty cielesne [...]. A stamtąd wznosiliśmy się jeszcze głębiej ku Twoim dziełom rozmyślając, rozmawiając i podziwiając je. I dotarliśmy do naszych umysłów i przekroczyliśmy je, tak że wstąpiliśmy w krainę obfitości nieznającej braku, gdzie pasiesz Izraela na wieki na równinie prawdy i gdzie życie jest Mądrością [...]. I gdy rozmawialiśmy i wzdychaliśmy ku niej, dotknęliśmy jej na moment całkowicie skupionym sercem. (Conf. 9.10.24) $)^{30}$

Po kontemplacji nie następuje wprawdzie reverberatio ani repercussio (być może ma to związek z tym, że Augustyn jest już tutaj człowiekiem ochrzczonym), ale kontemplacja trwa krótki czas, podobnie zresztą jak poprzednie doświadczenia z ks. VII. Kontekst jest znowu wyraźnie relacyjny, choć Augustyn nie tyle stara się odrzucić Plotyński model wstępowania duszy czy porzucić mówienie o Bogu językiem neoplatońskim, ile raczej dokonać pewnej syntezy mistyki Plotyna z własnymi doświadczeniami zakorzenionymi w lekturze Pisma Świętego.

Relacyjność kontemplacji mistycznej ulega rozwinięciu w ostatnich (X-XIII) księgach Wyznań. Augustyn opisuje doświadczenie Boga we wnętrzu duszy poprzez swego rodzaju totalne doświadczenie osobowej, kochającej obecności, w której występują, przynajmniej, potencjalnie, wszystkie modalności zmysłów duchowych:

kocham swego rodzaju światło, i swego rodzaju dźwięk, i swego rodzaju woń, i swego rodzaju pokarm, i swego rodzaju miłosny uścisk, gdy kocham Boga

${ }^{29}$ Głównie Enn. 5.1.

${ }^{30}[. .$.$] cumque ad eum finem sermo perduceretur, ut carnalium sensuum delectatio quanta-$ libet, in quantalibet luce corporea, prae illius vitae iucunditate non comparatione sed ne commemoratione quidem digna videretur, erigentes nos ardentiore affectu in idipsum, perambulavimus gradatim cuncta corporalia et ipsum caelum, unde sol et luna et stellae lucent super terram. et adhuc ascendebamus interius cogitando et loquendo et mirando opera tua. et venimus in mentes nostras et transcendimus eas, ut attingeremus regionem ubertatis indeficientis, ubi pascis Israhel in aeternum veritate pabulo, et ibi vita sapientia est, per quam fiunt omnia ista, et quae fuerunt et quae futura sunt, et ipsa non fit, sed sic est ut fuit, et sic erit semper. quin potius fuisse et futurum esse non est in ea, sed esse solum, quoniam aeterna est: nam fuisse et futurum esse non est aeternum. et dum loquimur et inhiamus illi, attingimus eam modice toto ictu cordis. et suspiravimus et reliquimus ibi religatas primitias spiritus et remeavimus ad strepitum oris nostri, ubi verbum et incipitur et finitur. et quid simile verbo tuo, domino nostro, in se permanenti sine vetustate atque innovanti omnia? 
mego. Światło, dźwięk, woń, pokarm, uścisk w moim wewnętrznym człowieku, gdzie rozbłyska duszy mojej coś, czego przestrzeń nie obejmuje, gdzie brzmi coś, czego bieg czasu nie porywa ze sobą, gdzie pachnie coś, czego tchnienie nie rozprasza, gdzie smakuje coś, czego ilości żarłoczność nie pomniejsza i gdzie lgnie do mnie coś, do czego nie zniechęca nasycenie miłości. To właśnie kocham, gdy kocham Boga mego. (Conf. 10.6.8) ${ }^{31}$

Nieco później Augustyn próbuje dokonać integracji neoplatońskiej mistyki Światła i Bytu z biblijnym doświadczeniem osobowej obecności. Zaczyna od konwencjonalnie Plotyńskiego opisu Boga jako Piękności, która jest nieustannie wewnątrz jego duszy, a on jej nie dostrzegał, gdyż był odwrócony na zewnątrz, ku doświadczeniom zmysłowym.

Późno cię umiłowałem, piękności tak dawna, a tak nowa, późno cię umiłowałem! Oto byłaś wewnątrz, a ja na zewnątrz, i tam ciebie szukałem i wśród tych rzeczy pięknych, które stworzyłaś, ja, bynajmniej nie piękny, błąkałem się. Byłaś ze mną, a ja nie byłem z tobą. One mnie trzymały z daleka od ciebie, rzeczy, które gdyby nie istniały w tobie, w ogóle by nie istniały. (Conf. 10.27.38) $)^{32}$

$\mathrm{Na}$ początku mamy klasyczną doktrynę neoplatońską, doktrynę upadku duszy: odwraca się ona od siebie samej i gubi się w świecie wielości, tracąc z oczu obecność Boga, który jest w duszy i w którym są wszystkie istniejące rzeczy. Nawet miłość, o której mowa na początku, to platoński eros, czyli pragnienie wyrastające z piękności absolutnej Zasady. Jednak teraz następuje coś zgoła nieoczekiwanego:

Zawołałaś, zakrzyknęłaś i rozdarłaś zasłonę mojej głuchoty. Zajaśniałaś, zabłysnęłaś i przegnałaś moją ślepotę. Zapachniałaś, wziąłem wdech i oddycham tobą. Skosztowałem, i łaknę, i pragnę. Dotknęłaś mnie i zapłonąłem żądzą twego pokoju. Gdy przylgnę do ciebie całym sobą, nie będzie już dla mnie cierpienia i trudu, a życie moje będzie żywe, całe pełne ciebie. (Conf. 10.27.38-28.39) ${ }^{33}$

${ }^{31}[. .$.$] non haec amo, cum amo deum meum, et tamen amo quandam lucem et quandam vocem$ et quendam odorem et quendam cibum et quendam amplexum, cum amo deum meum, lucem, vocem, odorem, cibum, amplexum interioris hominis mei, ubi fulget animae meae quod non capit locus, et ubi sonat quod non rapit tempus, et ubi olet quod non spargit flatus, et ubi sapit quod non minuit edacitas, et ubi haeret quod non divellit satietas. hoc est quod amo, cum deum meum amo.

32 [...] sero te amavi, pulchritudo tam antiqua et tam nova, sero te amavi! et ecce intus eras et ego foris, et ibi te quaerebam, et in ista formosa quae fecisti deformis inruebam. mecum eras, et tecum non eram. ea me tenebant longe a te, quae si in te non essent, non essent.

33 [...] vocasti et clamasti et rupisti surditatem meam; coruscasti, splenduisti et fugasti caecitatem meam; fragrasti, et duxi spiritum et anhelo tibi; gustavi et esurio et sitio; tetigisti me, et exarsi in pacem tuam. cum inhaesero tibi ex omni me, nusquam erit mihi dolor et labor, et viva erit vita mea tota plena te. 
Wytrawny retor pokazuje tutaj, jak Bóg, przedstawiony dopiero co w czysto Plotyńskich terminach, z jakąś namiętnością zniża się do duszy ludzkiej, żeby ją do siebie przyciągnąć, jak kobieta, która uwodzi mężczyznę, który ją był porzucił. Dla Plotyna to nonsens $-\mathrm{z}$ jakiego powodu miałoby Jedno opuszczać swój stan doskonałości i szczęścia, żeby kogoś wołać do siebie, kogoś dotykać itd. Co więcej, widać tutaj, że doświadczenie mistyczne jest doświadczeniem relacji, a nie jedności bez różnic, gdyż jest z jednej strony dusza, a z drugiej - głos, światło, zapach, pokarm i dotyk jako formy obecności Boga, który ją wypełnia sobą, jakby była naczyniem. Augustyn przylega i przywiera do Boga, a nie staje się z Nim jednym światłem bez różnicy.

Zmiana, której świadectwem są Wyznania, pisane w latach 397-401, dotyczy też ćwiczeń duchowych. Typowe neoplatońskie ćwiczenia, choć nadal są na tym etapie wykorzystywane, zostają uzupełnione o confessio, wyznawanie własnej grzeszności Bogu i głoszenie Jego wielkości i chwały oraz o modlitewną lekturę Pisma Świętego, alegoryczną egzegezę słowa Bożego ${ }^{34}$. W takiej medytacji nad Pismem także ujawnia się intensywna relacyjność kontaktu z Bogiem oraz odczucie własnej grzeszności i niepodobieństwa do Boga. Na przykład:

Czym jest to, co mi prześwituje i przeszywa moje serce nie raniąc go? Drżę wtedy z trwogi i płonę pragnieniem: drżę, o ile jestem do Niego niepodobny, a płonę pragnieniem, o ile jestem doń podobny. Mądrość, to Mądrość sama, która mi prześwituje, rozrywając moją chmurę, która mnie zaraz później znowu ogarnia, ułomnego z powodu tej ciemności i ciężaru mej kary. (Conf. 11.9.11)

Wskazałem tutaj na to, że z biegiem czasu w mistyce Augustyna coraz silniej dochodzi do głosu mistyka relacyjna, ale nie oznacza to, że Bóg traci swój metafizyczny status źródła bytu i poznania. Ten wątek nadal istnieje i Augustyn rozwija go np. w późnej stosunkowo XV księdze De Trinitate. Bóg jest tutaj nie tyle kochającą osobą, ile fundamentem poznania, światłem, w którym rozpoznajemy każdą prawdę. Doświadczenie mistyczne opisane zaś jest jako zwrócenie uwagi na samo to światło. Podobne wątki pojawiają się również w listach pisanych w tym okresie, czyli ok. 413-414 roku ${ }^{36}$. Przypomina to próbę odwrócenia uwagi od widzianych przez nas przedmiotów i zwrócenie jej na „samo widzenie”. Jest to ćwiczenie obecne często u Plotyna. Augustyn

34 Więcej o tym piszę w M. Stróżyński, Filozofia jako terapia w pismach Marka Aureliusza, Plotyna i Augustyna, Poznań 2014, s. 192-218.

${ }^{35}[. .$.$] quid est illud quod interlucet mihi et percutit cor meum sine laesione? et inhorresco et$ inardesco: inhorresco, in quantum dissimilis ei sum, inardesco, in quantum similis ei sum. sapientia, sapientia ipsa est quae interlucet mihi, discindens nubilum meum, quod me rursus cooperit deficientem ab ea caligine atque aggere poenarum mearum.

36 Por. Ep. 147.42 (do Pauliny) oraz Ep. 148.3 (do Fortunatiana). 
podkreśla jednak, że grzeszność duszy uniemożliwia jej wytrwanie w tym doświadczeniu:

Wznieś swoje oczy ku temu Światłu i wytrwaj w patrzeniu na nie, jeśli potrafisz. [...] Lecz by je w sposób jasny i oświetlony zobaczyć, nie potrafisz wytrwać w patrzeniu. Wiem to - nie potrafisz. Mówię prawdę, mówię to do samego siebie, bo wiem, że sam nie potrafię. (Trin. 15.50) (37 $^{37}$

W tym samym, przedostatnim rozdziale monumentalnego dzieła poświęconego Trójcy Augustyn powraca wciąż do faktu, że intelekt może - choć na czas jakiś - w tym życiu wpatrywać się w światło Boga obecne w nim samym. Zwracając się do własnej duszy, mówi bowiem:

Zdołałaś [scil. zobaczyć] nawet i ty, choć nie zdołałaś ani nie zdołasz wyjaśnić i wyrazić słowami w wystarczający sposób tego, co z trudem ujrzałaś między chmurami zmysłowych podobizn, które nie przestają nigdy osaczać ludzkich myśli. Lecz to Światło, które nie jest tobą, ukazało ci także i to, że czym innym są niecielesne podobizny rzeczy cielesnych oraz czym innym jest ta prawda, w którą się wpatrujemy naszym rozumieniem po odrzuceniu tych podobizn. Te i inne rzeczy w podobny sposób wewnętrznym oczom twoim to Światło ukazało. Cóż więc jest przyczyną tego, iż samego tego Światła nie jesteś w stanie stabilnym wzrokiem widzieć, jeśli nie jest nią zaiste słabość, a któż na ciebie słabość tę sprowadził, jeśli nie twoja nieprawość? (Trin. 15.50) ${ }^{38}$

Choć tak wyraźnie obecny jest tutaj metafizyczny sposób ujmowania Boga i Jego kontemplacji, kontekst pozostaje relacyjny. Grzech bowiem, który sprowadza słabość i uniemożliwia trwałą kontemplację, jest dla Augustyna przecież zerwaniem osobowej relacji z Bogiem. A kontekst ten podkreśla jeszcze modlitwa w ostatnim rozdziale De Trinitate, w której Augustyn prosi o łaskę kontemplacji i uzdrowienia, które jest jej warunkiem:

37 [...] et tamen multa uera uidisti, non his oculis quibus uidentur corpora colorata, sed eis pro quibus orabat qui dicebat: oculi mei uideant aequitatem. nempe ergo multa uera uidisti eaque discreuisti ab illa luce qua tibi lucente uidisti. attolle oculos in ipsam lucem et eos in ea fige si potes. [...] Sed ad hoc dilucide perspicueque cernendum non potes ibi aciem figere. Scio, non potest. Verum dico, mihi dico, quid non possim scio (Augustinus, De Trinitate libri XV. Libri XIII-XV, eds. W.J. Mountain, F. Glorie, s. 532).

$38[\ldots]$ potuisti et tu quamuis non potueris neque possis explicare sufficienti eloquio quod inter nubila similitudinum corporalium quae cogitationibus humanis occursare non desinunt uix uidisti. sed illa lux quae non est quod tu et hoc tibi ostendit aliud esse illas incorporeas similitudines corporum et aliud esse uerum quod eis reprobatis intellegentia contuemur. haec et alia similiter certa oculis tuis interioribus lux illa monstrauit. quae igitur causa est cur acie fixa ipsam uidere non possis nisi utique infirmitas, et quis eam tibi fecit nisi utique iniquitas? quis ergo sanat omnes languores tuos nisi qui propitius fit omnibus iniquitatibus tuis? (s. 533). 
Panie Boże mój, jedyna nadziejo moja, wysłuchaj mnie, bym ze zmęczenia nie zaniechał poszukiwania Ciebie, lecz bym zawsze żarliwie szukał oblicza Twego. Ty daj szukającemu siły, Ty, który sprawiłeś to, że zostałeś odnaleziony i coraz większą i większą nadzieję odnalezienia Ciebie dałeś. [...] Niech Ciebie pamiętam, niech Ciebie rozumiem, niech Ciebie kocham. Pomnażaj to we mnie, aż mnie przekształcisz i ostatecznie uzdrowisz. $(\text { Trin. } 15.51)^{39}$

Pamiętanie, rozumienie i kochanie to akty trzech władz umysłu - pamięci, intelektu i woli - które stanowią obraz Trójcy Świętej. Augustyn prosi tu więc o kontemplację Boga jako Trójcy poprzez Jego obraz, ludzki umysł, który poznając siebie, wznosi się ponad siebie.

Na koniec chcę powrócić jeszcze do Wyznań, które zwieńczone są niezwykle interesującym opisem, który nie ukazuje mistycznej kontemplacji w żaden z wcześniej omówionych sposobów - ani jako metafizycznego wpatrywania się w Światło Prawdy, ani jako zmysłowoduchowego odczucia kochającej obecności Boga w duszy. Tutaj Augustyn mówi, że jeśli ludzie

przez Ducha Twojego widzą te rzeczy [stworzone], Ty sam widzisz w nich. Gdy widzą, że są one dobre, Ty widzisz, że one są dobre i cokolwiek sprawia nam przyjemność ze względu na Ciebie, to Ty sam w tym sprawiasz nam przyjemność, a to, co nam sprawia przyjemność przez Ducha Twego, Tobie samemu sprawia przyjemność w nas. [...] Jak bowiem słusznie powiedziane jest: „,To nie wy bowiem jesteście tymi, którzy będą przemawiali” do tych, którzy przemawiać będą w Duchu Bożym, tak też słusznie powiedziane być może: „To nie wy jesteście tymi, którzy poznają” do tych, którzy w Duchu Bożym poznają. I wcale nie mniej słusznie powiedziane być może: „To nie wy jesteście tymi, którzy widzą” do tych, którzy w Duchu Bożym widzą. Dlatego cokolwiek widzą w Duchu Bożym, że jest dobre, to już nie oni widzą, lecz Bóg widzi, że jest dobre. (Conf. 13.31.46) ${ }^{40}$

To, co jest charakterystyczne w tym zdumiewającym w gruncie rzeczy opisie, to fakt, że Bóg staje się bardziej podmiotem widzenia niż Jego przedmiotem. Nie jest światłem, które się widzi jako przedmiot, jak we wczesnych doświadczeniach mistycznych Augustyna, nie jest już nawet wewnętrzną, ko-

39 [...] domine deus meus, una spes mea, exaudi me ne fatigatus nolim te quaerere, sed quaeram faciem tuam semper ardenter. tu da quaerendi uires, qui inueniri te fecisti et magis magisque inueniendi te spem dedisti. [...] Meminerim tui; intellegam te; diligam te. auge in me ista donec me reformes ad integrum (s. 534).

40 [...] qui autem per spiritum tuum vident ea, tu vides in eis. ergo cum vident quia bona sunt, tu vides quia bona sunt, et quaecumque propter te placent, tu in eis places, et quae per spiritum tuum placent nobis, tibi placent in nobis. [...] sicut enim recte dictum est, 'non enim vos estis, qui loquimini, ' eis qui in dei spiritu loquerentur, sic recte dicitur, 'non vos estis, qui scitis, 'eis qui in dei spiritu sciunt. nihilo minus igitur recte dicitur, 'non vos estis, qui videtis, 'eis qui in spiritu dei vident. ita quidquid in spiritu dei vident quia bonum est, non ipsi sed deus videt, quia bonum est. 
chającą obecnością, ale jest światłem, w którym się wszystko widzi, a nawet tym, który patrzy przez nasze oczy i kocha naszym sercem.

Jest to w jakimś sensie próba oddania stanu zjednoczenia, choć Augustyn wykazuje dużą ostrożność, by nie sugerować jedności duszy i Boga w tym stanie. Zjednoczenie to jest tak głębokie i ścisłe, że dusza staje się w zasadzie przezroczystym medium, przez które Bóg obecny w jej wnętrzu poznaje rzeczywistość i w niej działa. W zasadzie Bóg przez duszę i w duszy widzi i kocha samego siebie, skoro doświadczenie rzeczy dobrych przez chrześcijan Augustyn opisuje jako odczuwanie przez Boga przyjemności płynącej z Niego samego, bo On jest i podmiotem, i przedmiotem czasownika placere, użytego w tym miejscu. Jest to chyba najbardziej radykalna próba opisu wzajemnej intymności Boga i duszy, gdzie Bóg rzeczywiście okazuje się - jak to wcześniej Augustyn wspomina w ks. III - „,bardziej wewnętrzny niż to, co we mnie najbardziej moje oraz przewyższający to, co we mnie najwyższe"41.

\section{Wnioski}

Podsumowując ten szkic mistycyzmu Augustyna, warto jeszcze raz podkreślić jego zasadnicze elementy: (1) współistnienie dwóch nurtów: neoplatońskiego, metafizycznego poznania Boga jako niezmiennego Bytu, Prawdy i Światła oraz relacyjnego spotkania z Bogiem w miłości, (2) odrzucenie zjednoczenia przez niewiedzę z Absolutem, który jest ponad bytem, na rzecz wpatrywania się w różny od duszy boski Byt, (3) niemożliwą do pokonania w tym życiu grzeszność i słabość duszy, jej niepodobieństwo do Boga, które może zostać jedynie czasowo przekroczone w doświadczeniu kontemplacji, dzięki Jego łasce i uzdrawiającej aktywności w duszy.

Przytoczony finał Wyznań, wielki hymn na cześć Ducha Świętego widzącego, poznającego i kochającego samego siebie w swoich świętych i w całym stworzeniu, można uznać za syntezę tych wątków, ale też za wskazanie na coś więcej. Bóg okazuje się w tym miejscu niejako głębszym wymiarem ludzkiej podmiotowości. Jest, oczywiście, przedmiotem widzenia, jak w omawianych metafizycznych doświadczeniach oglądania Prawdy. Jest też tym, dzięki czemu widzimy, a zatem Światłem, w którym i którym widzimy rzeczywistość, jak w późnych rozważaniach zamieszczonych w De Trinitate. Jest też kochającą osobą, mieszkającą we wnętrzu duszy, w jej najbardziej własnych głębinach.

Jednak Augustyn w tym potężnym obrazie Ducha Bożego, rozlanego w sercach świętych, dodaje też wymiar tego, że Bóg jest jakby podmiotem stojącym za ludzkim podmiotem czy u jego podstawy - widzi naszymi oczami, rozumie

$41[\ldots]$ interior intimo meo et superior summo meo (Conf. 3.6.11). 
naszym intelektem, kocha naszą wolą świat stworzony i samego siebie w Nim. Nie ma tu wprawdzie ani Plotyńskiego zjednoczenia bez różnicy, gdzie w niewyrażalnie prostym świetle Jedna znika ten, który widzi, to, co widziane, i to, czym się widzi, ani śmiałości np. ojców kapadockich mówiących o przebóstwieniu i nazywających świętych „bogami”, jak to pisał Grzegorz z Nazjanzu o „Bogu z bogami zjednoczonym i przez bogów poznawanym” ${ }^{42}$. Wydaje się jednak, że Augustyn zmierza w tym kierunku i najbliżej jest tego właśnie w finale Wyznań, ale dogłębny duchowy i intelektualny kontakt z mistyką Plotyna nie tylko inspirował Augustyna, ale ostrzegał go też przed niebezpieczeństwem bałwochwalczego zrównania i utożsamienia duszy z Bogiem. Stąd ostrożność biskupa Hippony w używaniu pojęcia ,zjednoczenia” czy ,,jedności” i faworyzowanie języka poznawania, widzenia itd., w którym zawarta była dla niego immanentna odrębność. Jego koncepcja kontemplacji jest więc rozpięta między niezróżnicowanym, prostym światłem Plotyna a chrześcijańskim, wschodnim ideałem człowieka „stającego się Bogiem” i próbuje znaleźć ostrożny wyraz dla fenomenu mistycznego zjednoczenia człowieka z Bogiem w akcie kontemplacji.

Wskazane tu wątki zawierają, niekiedy w zalążku, większość najważniejszych motywów późniejszego mistycyzmu zachodniego chrześcijaństwa. Od czasów Augustyna bowiem aż do XII wieku i do Wilhelma od św. Teodoryka zachodnie chrześcijaństwo unikać będzie radykalnego języka jedności Boga i człowieka, naznaczone w dużej mierze dylematami samego biskupa Hippony, wywierającego ogromny, przytłaczający niekiedy wpływ na zachodnie chrześcijaństwo. Wilhelm od św. Teodoryka, podobnie jak ten ostatni, w Duchu Świętym będzie szukał najtrafniejszego sposobu opisania jedności mistycznej ${ }^{43}$, ale już po nim zacznie pojawiać się tendencja, która taki opór budziła u Augustyna, wyrażająca się w pismach włoskich mistyków franciszkańskich (Jacopone z Todi, Aniela z Foligno), flamandzkich i francuskich beginek (Jadwiga z Antwerpii, Beatrycze z Nazaretu, Małgorzata Porete) oraz Mistrza Eckharta i jego nadreńskich uczniów. W niej porzucona zostanie ostrożność wypracowana przez Augustyna i powróci nieoczekiwanie Plotyńskie „,zjednoczenie bez różnicy" (zapośredniczone przez neoplatońską teologię Pseudo-

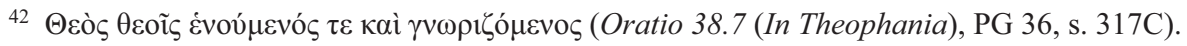

${ }^{43}$ Zob. np. Expositio super Cantica Canticorum 95 albo De contemplando Deo 11. McGinn pisze: "Bernard of Clairvaux, we recall, refused to allow the neuter form of the adjective (unum) to qualify our union with God, because it might suggest becoming 'one thing'. William apparently had no such qualms. William also stresses how the unitas spiritus is realized by our share in the unitas consubstantialitatis of the Trinity, a position that Bernard would probably have felt uncomfortable with" - B. McGinn, The Presence of God, vol. 2: The Growth of Mysticism, New York 1994, s. 266. Możemy dodać, że równie, jeśli nie bardziej, „uncomfortable” czułby się z tym i sam Augustyn, jak starałem się wykazać w niniejszych rozważaniach. 
-Dionizego Areopagity i Jana Szkota Eriugeny), które wraz z grecką teologią przebóstwienia zrodzi fascynującą i kontrowersyjną mistykę wieku XIII i XIV, tzw. mistykę spekulatywną, istotową (Wesensmystik).

\title{
CONTEMPLATION OF GOD IN ST. AUGUSTINE IN THE PERSPECTIVE OF THE EVOLUTION OF HIS PHILOSOPHY
}

\author{
Summary
}

The article is a brief survey of the view of Augustine on the contemplation of God from the point of view of the evolution of his thought, since the early period, when it was dominated by Plotinus and his Neoplatonism, until the mature phase, when the emphasis on the Scripture became much more significant. Augustine's mysticism seems to be a synthesis of a more metaphysical, Neoplatonic experience of God as the ground of being with a relational, love mysticism, based on the experience of God as "Thou". Even though the relational dimension is present in Augustine's mysticism from the very beginning it becomes much more important in his later works.

Key words: Augustine; Plotinus; contemplation; mysticism; spiritual exercise

Słowa kluczowe: Augustyn; Plotyn; kontemplacja; mistycyzm; ćwiczenia duchowe

\section{BIBLIOGRAFIA}

Alfaric P., L'evolution intellectuelle de Saint Augustin, Paris 1918.

Atkinson M., Plotinus: Ennead V.1. On the Three Principal Hypostases. A Commentary with Translation, Oxford 1983.

Boyer C., Christianisme et Neo-platonisme dans la formation de saint Augustin, Paris 1920.

Carabine D., The Unknown God: Negative Theology in the Platonic Tradition, Plato to Eriugena, Louvain 1995.

Cayré F., Initiation à la philosophie de saint Augustin, Paris 1947.

Chevallier L., Ronder H., L'idée de Vanité dans l'oeuvre de saint Augustin, „Revue des Études Augustiniennes" 3 (1957), s. 221-234.

Courcelle P., Recherches sur les Confessions de saint Augustin, Paris 1968.

Crouse R., Paucis mutatis verbis: St. Augustine's Platonism, w: Augustine and His Critics: Essays in Honour of Gerald Bonner, red. R. Dodaro, G. Lawless, London-New York 2000, s. 37-50.

Cary P., Augustine's Invention of the Inner Self. The Legacy of a Christian Platonist, Oxford 2000.

Dembińska-Siury D., Byt i istnienie w filozofii Plotyna, Warszawa 1979.

Dobell B., Augustine's Intellectual Conversion: the Journey from Platonism to Christianity, Cambridge 2009.

Dodds E.R., Augustine's Confessions: a study of spirituals maladjustment, "Hibbert Journal" 26 (1926-1927), s. 459-473. 
Kenney J.P., Contemplation and Classical Christianity: a Study in Augustine, Oxford 2013.

Kevane E., Christian Philosophy: the Intellectual Side of Augustine's Conversion, "Augustinian Studies" 17 (1986), s. 49-83.

Legowicz J., Historia filozofii starożytnej Grecji i Rzymu, Warszawa 1973.

Lossky V., Les elements de «Théologie négative» dans la pensée de saint Augustin, w: Augustinus Magister, t. 2, Paris 1954, s. 575-581.

Madec G., Pour l'amour de l'intelligence (Augustin, Lettre 120, à Consentius). Foi - Raison - Intelligence, w: Augustinus Afer. Actes du colloque international Alger-Annaba, 1-7 avril 2001. Saint Augustin: africanité et universalité, (Paradosis, 45, 1-2), red. P.Y. Fux, J.M. Roessli, O. Wermelinger, Fribourg 2003, s. 237-241.

Madec G., Une lecture de Confessions VII.9.13-21.27 (Notes critiques à propos d'une thèse de R.J. O'Connell), "Revue des Études Augustiniennes" 16 (1970), s. 79-137.

Marrou H.I., Saint Augustin et la fin de la culture antique, Paris 1958.

Mandouze A., Saint Augustin, l'aventure de la raison et de la grâce, Paris 1968.

Martin T.F., Book Twelve: Exegesis and Confessio, w: A Reader's Companion to Augustine's Confessions, red. K. Paffenroth, R.P. Kennedy, Louisville-London 2003, s. 185-206.

McGinn B., The Presence of God, t. 2: The Growth of Mysticism, New York 1994.

McGinn B., The Presence of God, t. 1: The Foundations of Mysticism, New York 1991.

Meconi D.V., The One Christ: St. Augustine's Theology of Deification, Washington 2013.

Meijer P.A., Plotinus on the Good or the One (Enneads VI.9). An Analytical Commentary, Amsterdam 1992.

O'Connell R.J., St. Augustine's Confessions. The Odyssey of Soul, New York 2003.

O'Connell R.J., Where the Difference Still Lies”, „Augustinian Studies” 21 (1990), s. 139-152.

O'Connell R.J., Augustine's Early Theory of Man, A.D. 386 - 391, Cambridge 1968.

Rigby P., The Theology of Augustine's Confessions, Cambridge 2015.

Rist J.M., Augustine: Ancient Thought Baptized, Cambridge 1994.

Sorabji R., Time, Mysticism, and Creation, w: Augustine's Confessions. Critical Essays, red. W.E. Mann, Oxford 2006, s. 209-236.

Stead C., Philosophy in Christian Antiquity, Cambridge 1994.

Stróżyński M., Neoplatonism in Augustine's Letters, w: Scrinium Augustini. The World of Augustine's Letters. Proceedings of the International Workshop on Augustine's Correspondence, Toruń, 25-26 June 2015, red. P. Nehring, M. Stróżyński, R. Toczko, Turnhout 2017 (w druku).

Stróżyński M., Mistyka jaźni w filozofii Plotyna, „Filozofia Chrześcijańska” 13 (2016), s. 97-120.

Stróżyński M., Filozofia jako terapia w pismach Marka Aureliusza, Plotyna i Augustyna, Poznań 2014.

Stróżyński M., Plotyn, O Dobru albo o Jednym (Enneada VI, 9), „Studia Antyczne i Mediewistyczne", 6, 41 (2008), s. 79-107.

TeSelle E., Porphyry and Augustine, „Augustinian Studies” 5 (1974), s. 113-147.

Teske R., To Know God and the Soul: Essays on the Thought of Saint Augustine, Washington 2008.

Theiler W., Porphyrios und Augustine, Halle 1933.

Van Fleteren F., Augustine and Philosophy, „Augustinian Studies” 41, 1 (2010), s. 255-274.

Van Geest P., The Incomprehensibility of God: Augustine as a Negative Theologian, Leuven-Paris 2011.

MATEUSZ STRóżYŃSKi (ur. 1979) - filolog klasyczny, filozof, psycholog, psychoterapeuta. W 2007 roku obronił pracę doktorską na temat mistyki Plotyna (wydana jako Mystical Experience and Philosophical Discourse in Plotinus, Poznań 2008), a w 2014 roku uzyskał stopień doktora habilitowanego na podstawie rozprawy Filozofia jako terapia w pismach Marka Aureliusza, Plotyna i Augustyna 
(Poznań 2014). Interesuje się mistycyzmem, kontemplacją i ćwiczeniami duchowymi w antyku i średniowieczu, zwłaszcza Plotynem, Augustynem i mistyką XIII i XIV wieku. Jego artykuły na temat filozofii Augustyna ukazały się m.in. w czasopismach „Phronesis”, „Vigiliae Christianae”, „Augustinian Studies” i „Augustiniana", a jego ostatnie publikacje to pierwszy polski przekład i komentarz do dzieła św. Anieli z Foligno, Zapiski (Poznań 2016) oraz redakcja pracy zbiorowej Scrinium Augustini. The World of Augustine's Letters (Turnhout 2017, razem z P. Nehringiem i R. Toczką). Pracuje jako adiunkt w Instytucie Filologii Klasycznej UAM w Poznaniu. 